"Mircea cel Batran" Naval Academy Scientific Bulletin, Volume XIX - 2016 - Issue 2

The journal is indexed in: PROQUEST / DOAJ / Crossref / EBSCOhost / INDEX COPERNICUS / DRJI / OAJI I JOURNAL INDEX / I2OR / SCIENCE LIBRARY INDEX / Google Scholar / Academic Keys/ ROAD Open Access I

Academic Resources / Scientific Indexing Services / SCIPIO / JIFACTOR

\title{
WAYS TO MEASURE CERTAIN SPECIFIC PARAMETERS DRAWING PROCESS
}

\section{Aurelia CHIOIBAS ${ }^{1}$}

${ }^{1}$ Lecturer eng, Ph. D., Dep. IMAN, Naval Academy "Mircea cel Batran", chioibasaura@yahoo.com

Abstract: For proper conduct of thin sheet metal drawing process it is necessary to know the size and variation work force during the power stroke. One method of measuring forces involves using transducers resistive strain gauge, which is based on the property of electrical conductors to electrical resistance change lengthening or shortening to them. The principle of this method consists in measuring the variation in resistance of an electrical conductor insulated and fixed to a metal spring which acts on the external force which causes elastic deformation as the workpiece and the conductor. At the force variation, varying the electrical resistance of the conductor, through calibration can establish a link between the force acting and intensity variation of voltage or a current that flows through the conductor that can be conveniently measured by means of electrical measurement. Dynamometric sensing device used to measure the deformation force needed.

Key words: the die, the punch, the drawing force, stroke of punch

\section{Introduction}

In this paper we present the experimental results obtained on the diagram force - stroke to the

processing by drawing successive strip of small parts in two steel grades.

Semi-finished and finished parts

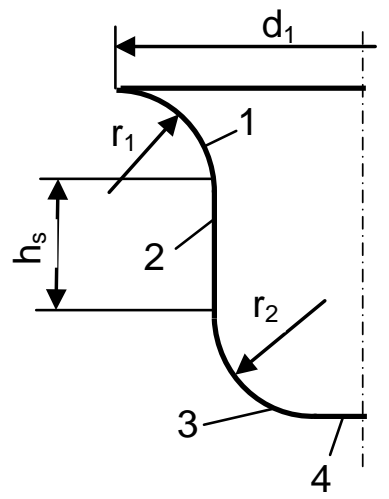

Fig.1. The configuration of piece drawing

Table 1. Experimental program $3^{2}\left(r_{p}=2 \mathrm{~mm}, r_{m}=2 \mathrm{~mm}\right)$

\begin{tabular}{|c|c|c|c|c|c|c|c|c|c|c|c|}
\hline \multirow{2}{*}{$\begin{array}{c}\mathrm{Nr} . \\
\exp \end{array}$} & \multicolumn{3}{|c|}{$\begin{array}{c}\text { Coefficients } \\
\text { drawing }\end{array}$} & $\begin{array}{c}\mathrm{d}_{\mathrm{p}} \\
{[\mathrm{mm}]}\end{array}$ & $\begin{array}{c}\mathrm{j} / 2 \\
{[\mathrm{~mm}]}\end{array}$ & $\begin{array}{c}\mathrm{d}_{\mathrm{m}} \\
{[\mathrm{mm}]}\end{array}$ & $\begin{array}{c}\mathrm{D}_{\text {semif }} \\
{[\mathrm{mm}]}\end{array}$ & $\mathrm{k}$ & $\begin{array}{c}\mathrm{A} \\
{\left[\mathrm{mm}^{2}\right]}\end{array}$ & $\begin{array}{c}\mathrm{F}_{\mathrm{a}} \\
{[\mathrm{N}]}\end{array}$ & $\begin{array}{c}\mathrm{Q} \\
{[\mathrm{N}]}\end{array}$ \\
\hline & $\mathrm{m}$ & $\mathrm{m}_{\mathrm{y}}$ & $\mathrm{m}_{\mathrm{glt}}$ & & & & & & & \\
\hline 1 & 0.55 & 0.6 & 0.327 & 5.52 & 0.24 & 6 & 11 & 0.75 & 0.0 & 1074.9 & 0.0 \\
\hline 5 & 0.50 & 0.8 & 0.400 & 7.86 & 0.32 & 8.5 & 17 & 0.9 & 83.8 & 2442.4 & 209.6 \\
\hline
\end{tabular}

Following of design [1] of piece cylindrical shape with a flat bottom (Fig. 1) have resultedthe parameters presented in Table 1 Were noted:

$$
\begin{aligned}
& m=\text { the drawing coefficient; } \\
& m_{y}=\text { the thinning coefficient; }
\end{aligned}
$$

$\mathrm{m}_{\mathrm{glt}}=$ the global total admissible coefficient;

$\mathrm{d}_{\mathrm{p}}=$ the punch diameter;

$\mathrm{d}_{\mathrm{m}}=$ the die diameter;

$\mathrm{j}=$ the clearance between the active elements;

$D_{\text {semif }}=$ the blank diameter; 
"Mircea cel Batran" Naval Academy Scientific Bulletin, Volume XIX - 2016 - Issue 2

The journal is indexed in: PROQUEST / DOAJ / Crossref / EBSCOhost / INDEX COPERNICUS / DRJI / OAJI I JOURNAL INDEX / I2OR / SCIENCE LIBRARY INDEX / Google Scholar / Academic Keys/ ROAD Open Access I Academic Resources / Scientific Indexing Services / SCIPIO / JIFACTOR

$\mathrm{k}=$ coefficient chosen $[\mathrm{R} 6]$ to calculate the force of drawing;

$A=$ the area that is blank retaining;

$\mathrm{F}_{\mathrm{a}}=$ the drawing force,

$\mathrm{Q}=$ the retaining force;

$r_{p}=2 \mathrm{~mm}$, is the punch radius,

$r_{m}=2 \mathrm{~mm}$, is the die radius.

The blank used is a thin tape with a thickness $\mathrm{g}=$ $0.4 \mathrm{~mm}$ and width $\mathrm{B}=22 \mathrm{~mm}$, which were nicked at different diameters, in order to avoid tearing it during processing. We used two types of annealed steel, A3k and A5 [2]. The drawing was performed by deliberate thinning of the wall thickness. In the design phase involved the execution nicking of the following operations (Fig. 2):

a) Perforation of the tape with a diameter of $5.5 \mathrm{~mm}$, for positioning the blank in the direction of advance;

b) the execution nicking of the tape after two diameters: $\mathrm{d}$ । nick $=11 \mathrm{~mm}$ and $\mathrm{d}$ || nick $=17 \mathrm{~mm}$.

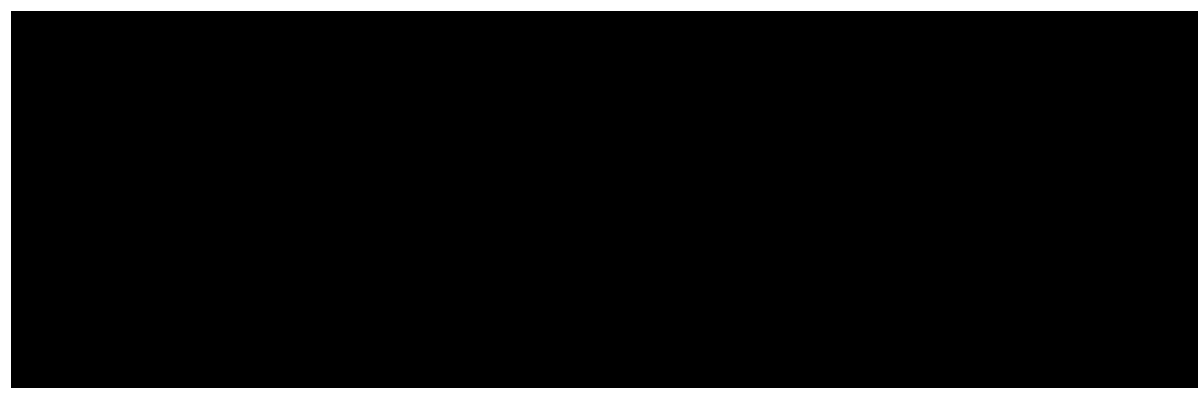

Figure 2. Design the execution nicking of the tape

The tapessuch processed are presented infig. 3.

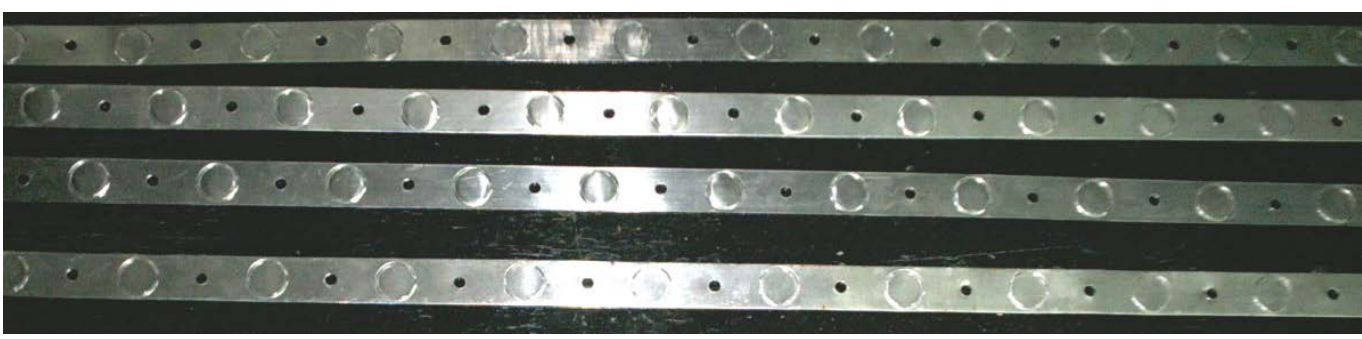

Figure 3. The blanks tape used in accordance with experimental program

The equipment used for processing by drawing the tape

Experimental stand was made up of eccentric mechanical press type PAI 16 that was installedthe drawing die dynamometric research. Obtaining of the parts involved changing and installing ondiethecorresponding active elements each experience. To know the variation that has the force along the race was necessary to installondie of the sensor dynamometer, and onslipper was installed inductive displacement transducer. The signals collected from the sensor and transducers were amplified of electronically strain gaugeand transmitted for amplification and visualization of an oscillograph.

The construction of the dynamometric die To perform the research experiences of small parts drawing was used the diedynamometricwith active element quickly change shown in Figure 4
[3]. It was built for drawing individual blanks, but was adapted for successive drawing tape.

The support die is made up of two guide columns formed in the base plate 6 , the guide columns 20 equipped withelastic retaining ring 7 and the head plate 23 with the guide bushings 22 and spigot retainer 24 fixed with the screws 25 .

In order to provide a rapid change of the active elements, the active plate 13 is designed as a support plate-pad, guided by the columns 20, which allows placing and the centering of the active elements ring 8 with a snug fit with zero minimum clearance. The centering semi-finished products of different diameters relative to the axis of the punch is made by means of rings 9 arranged with a minimum clearance snug fit in the annular channel which is provided the active plate.

(C) 2015. This work is licensed under the Creative Commons Attribution-Noncommercial-Share Alike 4.0 License. 
"Mircea cel Batran" Naval Academy Scientific Bulletin, Volume XIX - 2016 - Issue 2

The journal is indexed in: PROQUEST / DOAJ / Crossref / EBSCOhost / INDEX COPERNICUS / DRJI / OAJI I JOURNAL INDEX / I2OR / SCIENCE LIBRARY INDEX / Google Scholar / Academic Keys/ ROAD Open Access I

Academic Resources / Scientific Indexing Services / SCIPIO I JIFACTOR

The punches 27 , with the active part with different diameters, are assembled to the head plate by a zero minimum clearance snug fitand rests axially on the spigot flange. For fixing against of pulling apart during removal of drawing piece from the punch was provided on the tail of each punch an annular channel into which the washer gutted 26 retained by hexagon screw heads 21 .

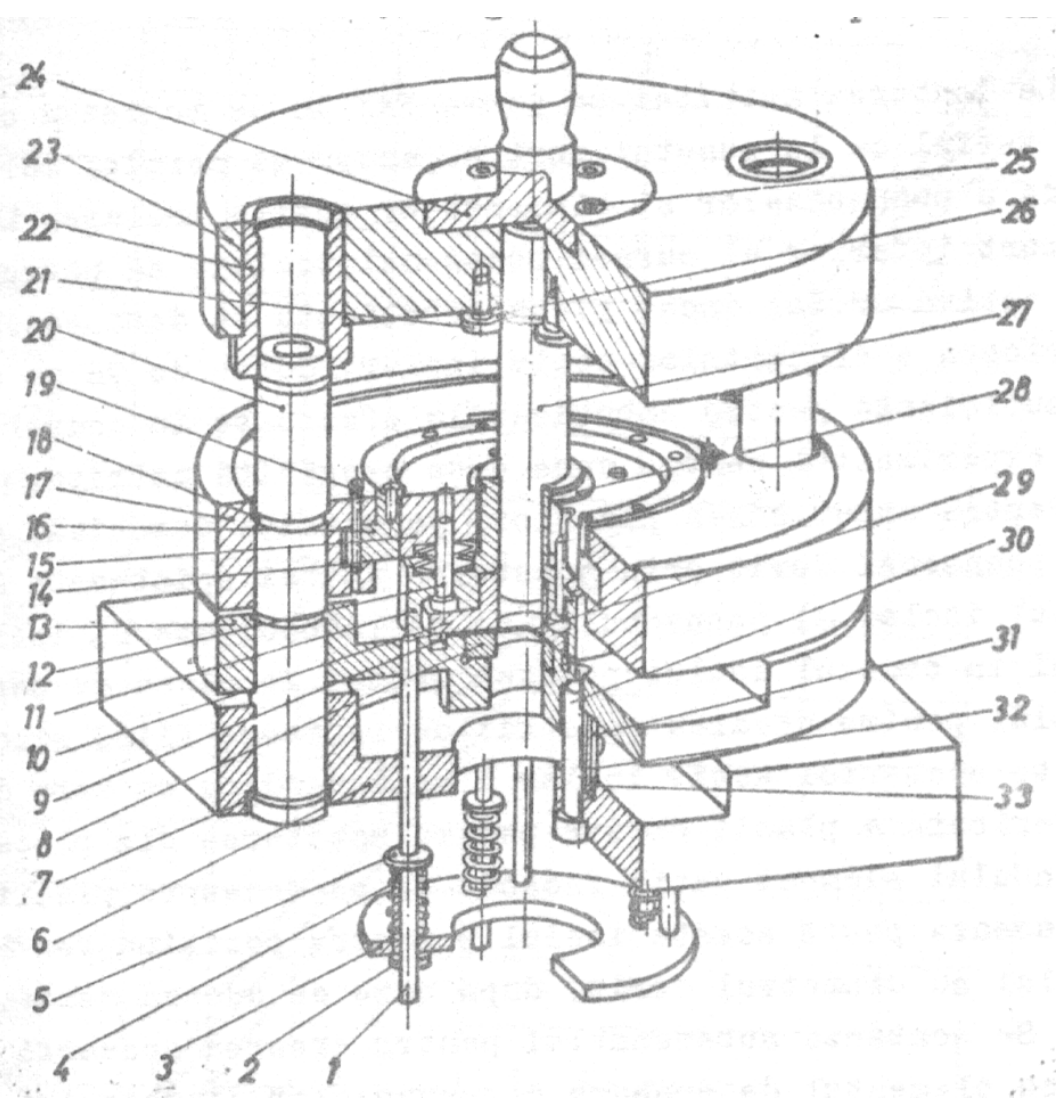

Figure 4.The dynamometricdie for drawing researche

Pressing the retaining of the flange blank is achieved by means the plate 17 , which is guided on two columns and retained against upward movement of the snap ring 18 and quickly removable subassembly. It is composed of 16 locking ring, the locking pin 19, threaded ring 15, disc springs 14 , centering pins 12 , the support press element 11 , the safety ring 28 and thrust element 10. Rapid installation and dismantling of this subassembly is possible due to the segmented flange of the latching ring 16 coming into channel segmented corresponding of the plate 17 and rotates clockwise until shoulder flange segment rests on the stud 19. Pressing the elastic retaining is achieved by screwing the threaded ring 15 with a studs key and send pressing element through the disc springs 14 . After the lock ring is rotated in the opposite direction subassembly is easily removed from the plate 17 by lifting his 1 rods with washers 5 , actuated coil springs 4, which rests on 3 ring linked to the base plate 6 by screws 2 .

To measure the force drawing and retention (which is adjustable) active plate 13 rests on base plate 6 through four spring elements 32.These have the shape some bushingand are subjected to compression.On they are fixed two strain gauges; one oriented along bushing axis and the other in a direction perpendicular thereto.

The link between active plate 13 and the base plate 6 is achieved using the screws with hexagon socket 30; at the same time, they also act as positioning bushings 32 through the washers33.The bushings spacers 31 ensure the implementation of a slight tightening bushing 32 .

To achieve continuous band drawing successive, drilling was required board to step in taking cupping $(17,6 \mathrm{~mm})$, because the part must be on where to go out when it exceeds height drawing die. 
"Mircea cel Batran" Naval Academy Scientific Bulletin, Volume XIX - 2016 - Issue 2 The journal is indexed in: PROQUEST / DOAJ / Crossref / EBSCOhost / INDEX COPERNICUS / DRJI / OAJI I JOURNAL INDEX I I2OR / SCIENCE LIBRARY INDEX / Google Scholar / Academic Keys/ ROAD Open Access I Academic Resources / Scientific Indexing Services / SCIPIO / JIFACTOR

In the plate on which support the drawing ring 13 has been required milling a channel width equal to the web $(22 \mathrm{~mm})$ in order to guide the blank.For use with band jagged which requires positioning in advance direction, it was mounted a pin in which be fixed the blank.

Drawings of punches, dies and retaining elements corresponding experimental program are shown in Figures 5, 6 and 7 [4].

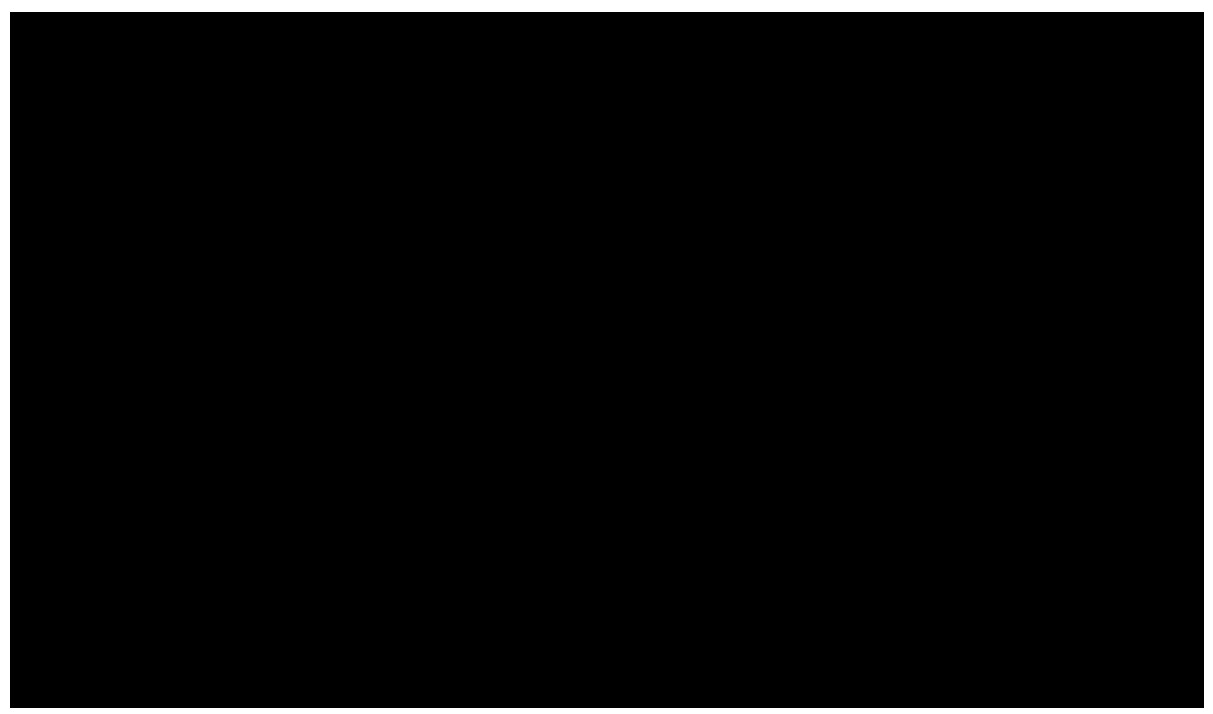

Fig. 5 Execution drawings of dies

Note:

1) The materialulof dies: C120 STAS 3611 - 80;

2) Heat treatment: Hardened-back;

3) Hardness: HRC 58-60;

4) There will be executed two dies, each having a diameter $d_{+0,0}^{+0,009}$ with table values;

5) Number of the die will burn the place indicated on the drawing. 
"Mircea cel Batran" Naval Academy Scientific Bulletin, Volume XIX - 2016 - Issue 2 The journal is indexed in: PROQUEST / DOAJ / Crossref / EBSCOhost / INDEX COPERNICUS / DRJI / OAJI / JOURNAL INDEX / I2OR / SCIENCE LIBRARY INDEX / Google Scholar / Academic Keys/ ROAD Open Access I Academic Resources / Scientific Indexing Services I SCIPIO I JIFACTOR

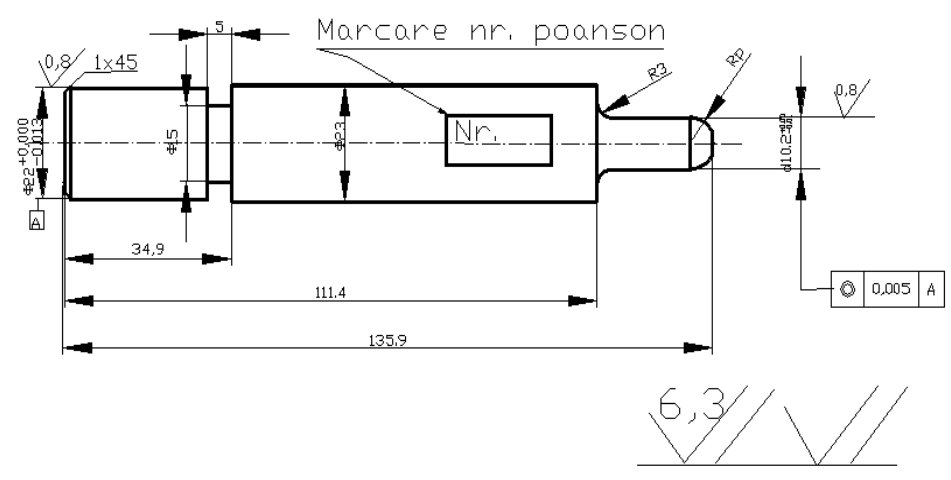

Fig. 6.Execution drawings of punches

\begin{tabular}{|c|c|}
\hline $\begin{array}{c}\text { Nr.of } \\
\text { die }\end{array}$ & $\begin{array}{c}\text { The diameter } \\
\mathrm{d}_{\mathrm{m}}[\mathrm{mm}]\end{array}$ \\
\hline 1. & 6 \\
\hline 5. & 8,5 \\
\hline
\end{tabular}

Note:

1) The material of punches: OSC8 STAS 1700 ;

2) Heat treatment: Hardened-back;

3) Hardness: HRC 58-60;
4) There will be executed two punches, each having a diameter $d_{-0,006}^{+0,0}$ with table values;

5) Number of the die will burn the place indicated on the drawing

\begin{tabular}{|c|c|c|}
\hline $\begin{array}{c}\text { Nr.of } \\
\text { punch }\end{array}$ & $\begin{array}{c}\text { The diameter } \\
\mathrm{d}_{\mathrm{p}}[\mathrm{mm}]\end{array}$ & $\begin{array}{c}\text { The radius } \\
\mathrm{R}_{\mathrm{p}}[\mathrm{mm}]\end{array}$ \\
\hline 1. & 5,52 & 2 \\
\hline 5. & 7,86 & 2 \\
\hline
\end{tabular}


"Mircea cel Batran" Naval Academy Scientific Bulletin, Volume XIX - 2016 - Issue 2 The journal is indexed in: PROQUEST / DOAJ / Crossref / EBSCOhost / INDEX COPERNICUS / DRJI / OAJI I JOURNAL INDEX / I2OR / SCIENCE LIBRARY INDEX / Google Scholar / Academic Keys/ ROAD Open Access I Academic Resources / Scientific Indexing Services / SCIPIO I JIFACTOR

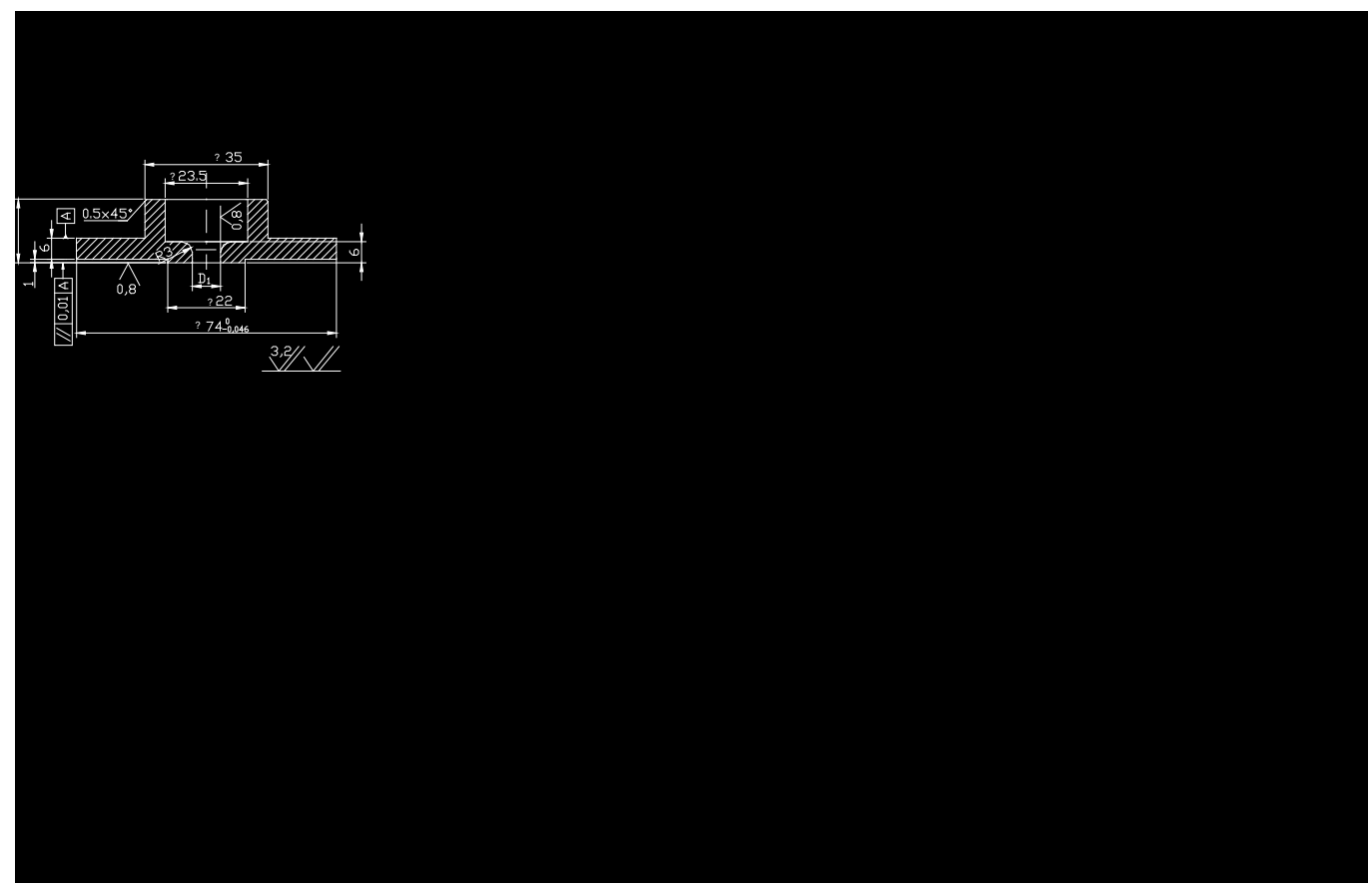

Fig. 7.Execution drawings of retaining elements

Note:

1) The material of retaining elements: C120 STAS $3611-80$;

2) Heat treatment: Hardened-back;

3) Hardness: 42-45 HRC;

4) There will be executed two retaining elements, accordance with table;

5) Number of the retaining elements will burn the place indicated on the drawing

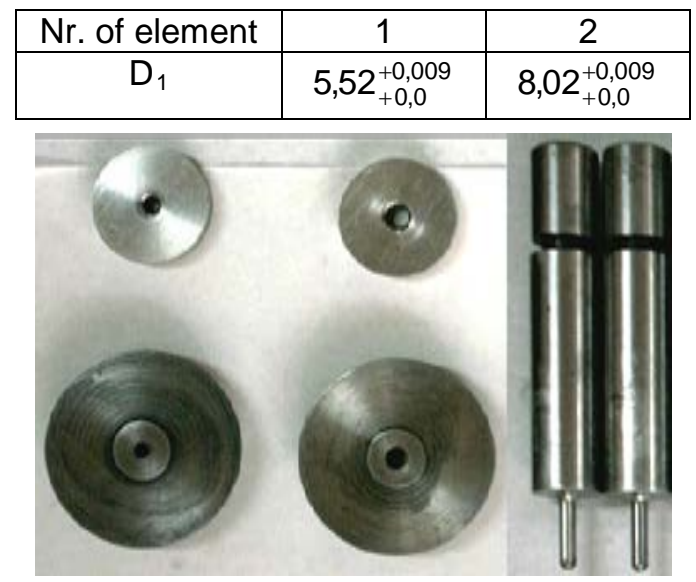

Figure 8. The active elements use in the experiments 
"Mircea cel Batran" Naval Academy Scientific Bulletin, Volume XIX - 2016 - Issue 2

The journal is indexed in: PROQUEST / DOAJ / Crossref / EBSCOhost / INDEX COPERNICUS / DRJI / OAJI I JOURNAL INDEX / I2OR / SCIENCE LIBRARY INDEX / Google Scholar / Academic Keys/ ROAD Open Access I Academic Resources / Scientific Indexing Services / SCIPIO I JIFACTOR

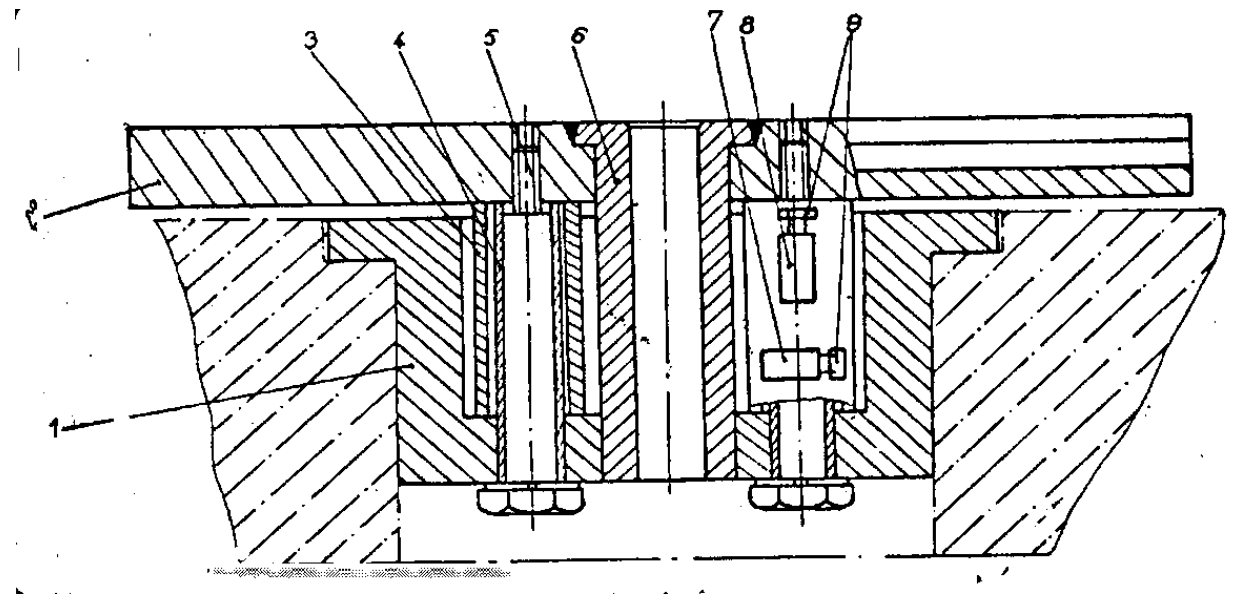

Figure 9. Dynamometer sensing device of die

\section{Dynamometer sensing device of die}

For optimal lead of the deformation process it is necessary to know the size and variation work force during the race. A method for measuring the forces requires the use of strain gauge resistive transducers ([5], [6]), which is based on the property of electrical conductors to the electrical resistance change to lengthening or shortening them. The principle of this method consists in measuring the variation of resistance of an electrical conductor insulated and fixed on the elastic metal piece, on which there acts an external force that causes elastic deformation of both the workpiece and the conductor.It is envisaged the determination of calibration curves by which to establish a link between the force acting and voltage variation or intensity of a stream that flows through the conductor, which can be measured conveniently using electric measuring instruments [7].

Dynamometric sensing device used to measure the deformation force needed. It is composed of cylindrical body 1 with flange which coming into hole of the press table; the collar of body leans on the recess of the table. Plate 2 integral with the tubular rod 6 (which is coaxial with the body 1 ), rests on this body through four elements elastic bushing type 3.These elements are requested compressive forces pressing. The spacers bushings 4 and the screws 5 ensure pre-tension and maintain the position of the elastic elements 3.The die is placed on the plate 2 and secured with clamps and screws channels T.Resistive strain gauge transducers are glued within each elastic element.Active transducers 8 are oriented parallel to bushing axis, and the transducers 7 are applied perpendicular to the axis of bushing. The main role of transducers 7 is to compensate the effect of variation temperature. Connection wires of the transducer are glued onto intermediate contacts 9.Strain gauge transducers have the paper support, the base of $10 \mathrm{~mm}, \mathrm{R}=120 \Omega$ and the sensitivity coefficient $K^{\prime}=2,1$. 
"Mircea cel Batran" Naval Academy Scientific Bulletin, Volume XIX - 2016 - Issue 2

The journal is indexed in: PROQUEST / DOAJ / Crossref / EBSCOhost / INDEX COPERNICUS / DRJI / OAJI I JOURNAL INDEX / I2OR / SCIENCE LIBRARY INDEX / Google Scholar / Academic Keys/ ROAD Open Access I Academic Resources / Scientific Indexing Services / SCIPIO I JIFACTOR

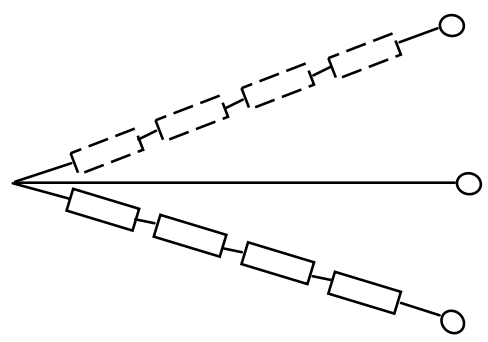

Figure 10. Installation electrical scheme in half bridge strain gauge of the transducers

The electrical scheme of mounting of the transducer strain gauge in the half bridge (Figure 10) ensuring the summation of the signals from the transducers for measurement, which are arranged along the axis of the bushings (dashed lines), and compensation for temperature variation by using the transducer compensation, which are arranged perpendicular to the axis of the bushings (represented in full lines).Under these conditions the assembly of the transducer is provided an amplification factor $\mathrm{K}_{\mathrm{m}}=1,3$.
The supply voltageof sensing device is $4 \mathrm{~V}$. Rated load of the sensor is $160 \mathrm{kN}$.

To measure forces drawing and retaining the preform flange has been done calibration of the dynamometer sensing device of die, which consisted in charging him with various tasks and relationship load capacity of $F$ [daN] and specific deformation $\varepsilon[\mu \mathrm{m} / \mathrm{m}]$ read on electronic straingauge.Maximum loading force was 11000 daN.That connection is shown in Figure 11 [3] in which curve traced by points resulted from experimental measurements and was approximated by right curve 1 and curve 2.It is noted that for $\mathrm{F} \leq 1000$ daN the bond is nonlinear, and for high values, there is linearity.

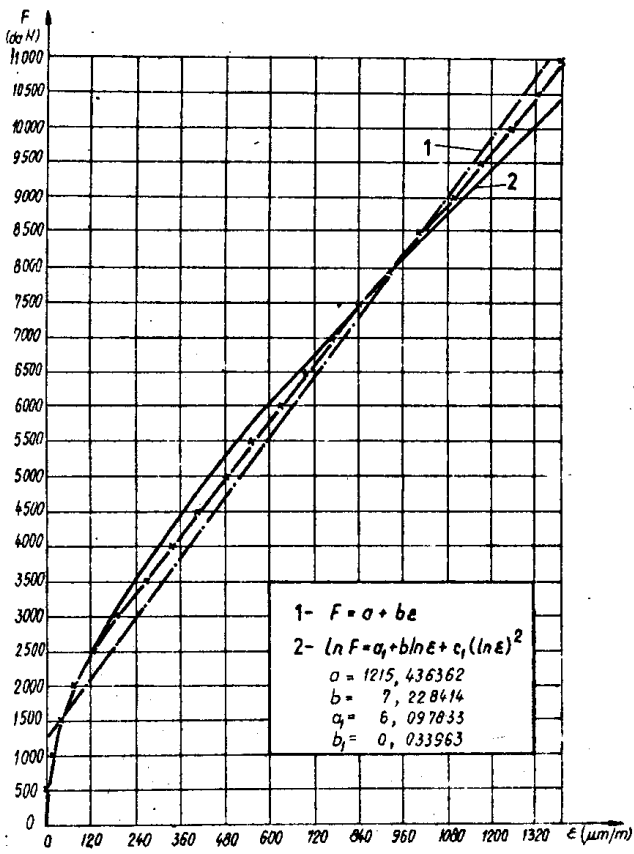

Figure 11. The calibration curves of the sensing device 
"Mircea cel Batran" Naval Academy Scientific Bulletin, Volume XIX - 2016 - Issue 2

The journal is indexed in: PROQUEST / DOAJ / Crossref / EBSCOhost / INDEX COPERNICUS / DRJI / OAJI /

JOURNAL INDEX / I2OR / SCIENCE LIBRARY INDEX / Google Scholar / Academic Keys/ ROAD Open Access I

Academic Resources / Scientific Indexing Services / SCIPIO I JIFACTOR

Calibration of equation 1 determines the measured force $\mathrm{F}>1000$ daN with errors less than $5 \%$ and has the expression:

$$
F=1215,436+7,228 \cdot \varepsilon \quad[\mathrm{daN}](1)
$$

The equation for the calibration curve 2 allows the determination of measured force $\mathrm{F}>500 \mathrm{daN}$, with errors of less than $5 \%$ and has the expression:

$$
\begin{aligned}
& \ln F=6,097833+0,189508 \cdot \ln \varepsilon+0,033963 . \\
& (\ln \varepsilon)^{2}[\text { daN] }
\end{aligned}
$$

Calibration equation for $F<1000$ daNwhich predicts the force measured with error less than $2 \%$ is:

$$
\mathrm{F}=77,647+104,1226 \cdot \varepsilon-3,052 \cdot \varepsilon^{2} \quad[\mathrm{daN}](3)
$$

\section{Inductive displacement transducer}

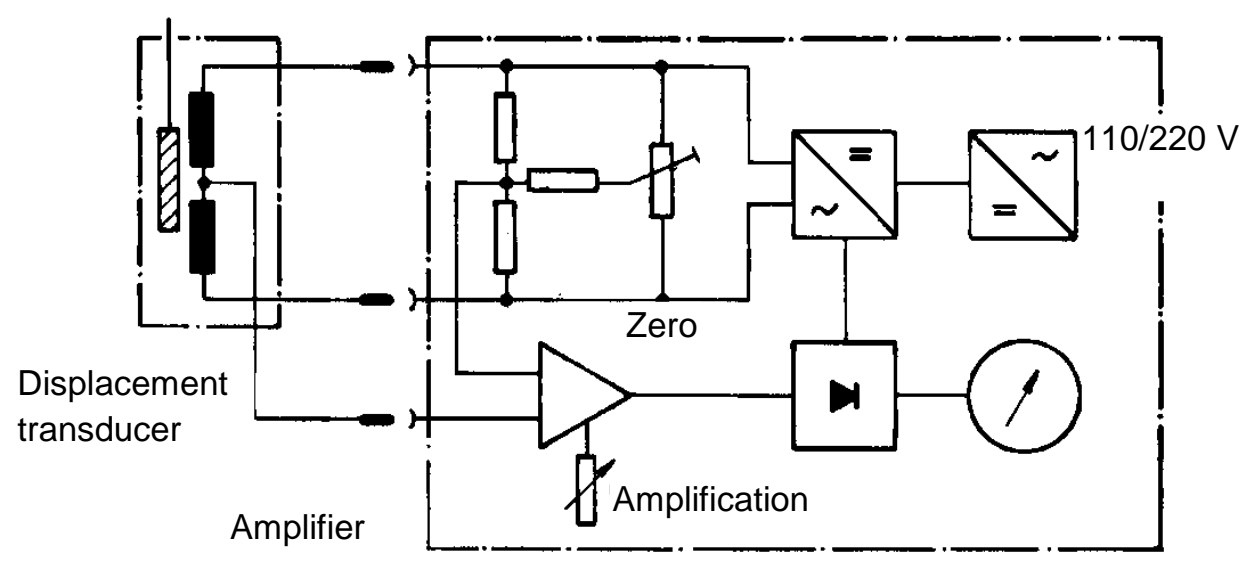

Figure 12. Inductive displacement transducer

Mechanical quantities such as distance, force, pressure, twisting, deformation and vibration can be transformed into displacements (using corresponding mechanical devices) and can be measured with inductive displacement transducers.It is composed of a cylindrical stainless steel body contains a differential coil and an axially displaceable plunger (Figure 12). The coil is coupled by means of a Wheatstone bridge to an amplifier.The movement of plunger entail a change to the coil impedance and unbalancing Wheatstone Bridge [8]. The inductive displacements transducer W10 series is powered at a frequency of $5 \mathrm{kHz}$ and a voltage of $1 \ldots 6 \mathrm{~V}$.

\section{Block diagram of measuring stand}

To measure and visualize force variation along the race are collected separately signals from the sensing device dynamometer and inductive transducer displacement (1), which are transmitted on two channels to the electronic strain-gauge (2), where they are amplified and then introduced in the oscilloscopes (3) for amplification and visualization (Figure 13 [7]). For this,uses the electronic strain-gauge with twochannelN-2321 and laboratory oscilloscope S813. 
"Mircea cel Batran" Naval Academy Scientific Bulletin, Volume XIX - 2016 - Issue 2

The journal is indexed in: PROQUEST / DOAJ / Crossref / EBSCOhost / INDEX COPERNICUS / DRJI / OAJI I JOURNAL INDEX / I2OR / SCIENCE LIBRARY INDEX / Google Scholar / Academic Keys/ ROAD Open Access I Academic Resources / Scientific Indexing Services / SCIPIO / JIFACTOR

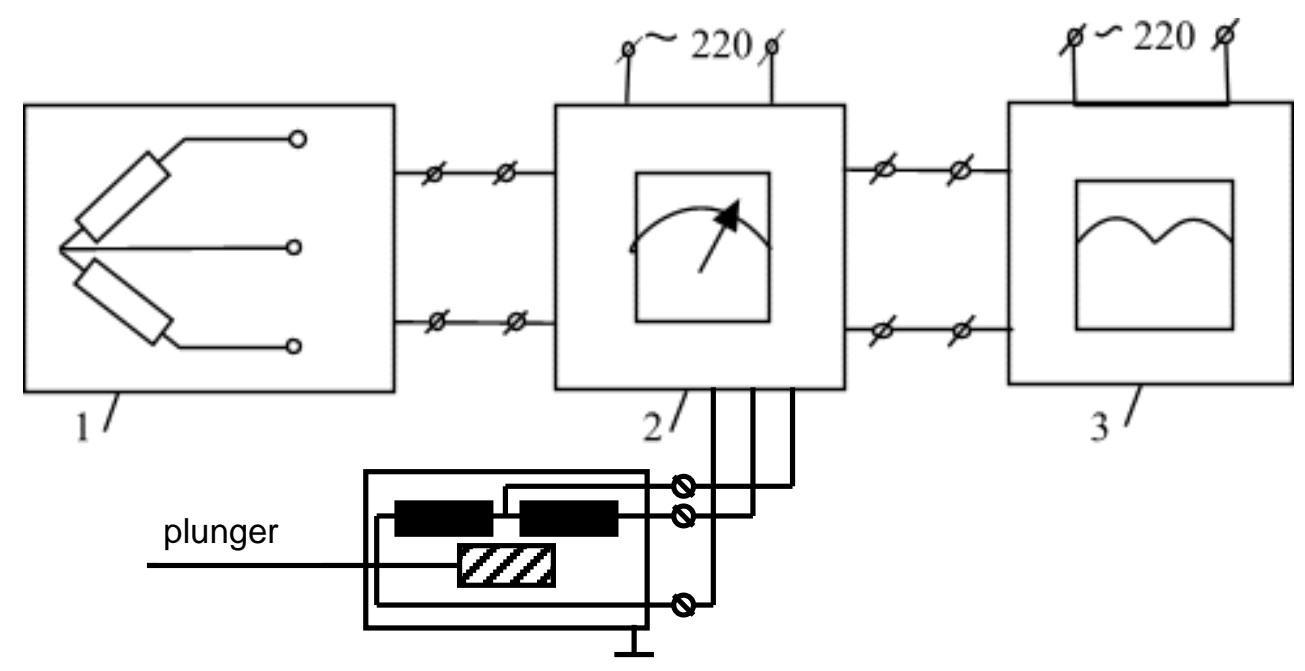

Figure 13.Block diagram of the stand

Jacks "Transducers" of the two channels (located on the back panel) is made connecting of the transducers on strain gauge electronic. Jacks "Exit" on the same panel used to connect of strain gauge electronic on oscillograph. The signal forces for vertical deflection is applied to the input "Y $\mathrm{A}$ " of the oscillograph and the signal displacementsfor horizontally deflection, on entry "X".

The calibration is done by establishing a relationship between displacement of the ram and horizontal deviation of the light spot on the oscillograph screen.

After composing horizontal deviation spot, due to displacement of the ram with the vertical, due to the variation force on oscillograph screen will get variation diagram of force along the course work.

Tensometry two-channel N-2321 allows simultaneous measurement (using inductive or resistive strain gauge sensing elements) of physical quantities such as force couples, pressure, displacements, etc.To connect the strain gauges will use two input channels. The first channel will connect a half bridge consists of a transducerresistive and a transducer resistive compensation, and the second, an inductive displacement transducer.The strain gauge electronic allows adjustment of pilot phase voltage for measuring, adjustment of pilot phase voltage on capacitive balance, gain control, choice of measurement scale, balancing fine, medium and grossresistive, coarse and fine capacitive balancing.

S8-13 oscilloscope is provided with an amplifier "Y" with two-channel, work in $0.50 \mathrm{MHz}$ band and has a sensitivity of $20 \mathrm{mV} /$ division. The time base of oscilloscope has three operating modes: automatic, triggered and mono-triggered.The

DOI: 10.21279/1454-864X-16-12-023

(C) 2015. This work is licensed under the Creative Commons Attribution-Noncommercial-Share Alike 4.0 License. oscilloscope has two rectangular signals calibration $1 \mathrm{kHz}$, with the amplitudes included from 120mV and 1,2V.Input signals can be connected directly by the low pass filter $(10 \mathrm{kHz}-$ $2 \mathrm{MHz}$ ) and high-pass filter $(2 \mathrm{MHz}-50 \mathrm{MHz})$.

Determining the optimal holding force and the values of specific strains

To determine the retaining force is used the oscilloscope with memory S8 - 13, which was set to scale $1 \mathrm{~V} /$ division and the strain gauge electronic with 2 channel $\mathrm{N}$ - 2321, which was set to scale $200 \mu \mathrm{m} / \mathrm{m}$. Following calibration of the two apparatus it has been found that a specific strain of 10 micrometres / $\mathrm{m}$ corresponds to a voltage of $20 \mathrm{~V}$.

As a result, the specific strain was calculated with the relationship:

$$
\varepsilon=0,5 \cdot U
$$

where $U[\mathrm{~V}]$ is the voltage measured at carrying out of experience.

Under these conditions equation of the calibration (3), be valid for $\mathrm{F}<1000$ daN becomes:

$$
F=77,647+52,0613 \cdot U-0,763 \cdot U^{2}
$$

Determining the value specific strain $\varepsilon$ to ensure the restraint force is made from relationship:

$$
3,052 \cdot \varepsilon^{2}+104,1226 \cdot \varepsilon-77,647+Q=0 .
$$

$$
\begin{aligned}
& \text { Result: } \\
& \qquad \varepsilon=17,058+\sqrt{316,41988-0,327654 \cdot Q} .
\end{aligned}
$$


"Mircea cel Batran" Naval Academy Scientific Bulletin, Volume XIX - 2016 - Issue 2

The journal is indexed in: PROQUEST / DOAJ / Crossref / EBSCOhost / INDEX COPERNICUS / DRJI / OAJI I JOURNAL INDEX / I2OR / SCIENCE LIBRARY INDEX / Google Scholar / Academic Keys/ ROAD Open Access I

Academic Resources / Scientific Indexing Services / SCIPIO I JIFACTOR

The retention force was calculated with the relationship:

$$
\mathrm{Q}=\mathrm{A}_{\mathrm{q}} \cdot \mathrm{q}=\frac{\pi}{4}\left[\mathrm{D}_{\text {crestare }}^{2}-\left(\mathrm{d}_{\mathrm{m}}+\mathrm{r}_{\mathrm{m}}\right)^{2}\right] \cdot \mathrm{q}
$$

Where in: $A_{q}$ - the retaining surface; the specific retaining pressure was considered for the steel $q$ $=0,3 \mathrm{daN} / \mathrm{mm}^{2}$ [9].

Calculated values of the optimal retaining force and specific strain are indicated in the table 2[4].

\section{Conducting experiments}

Their achievement required the following steps:

1. Equipping the die with the active elements for each experience;
2. Lubrication of blank and place it into the die;

3. Position adjustment of punch race for obtain the height part from the experimental program;

4. Adjusting the strain gauge electronic and oscillograph for making measurements;

5. Application of force to ensure optimum pressure retaining;

6. The zeroing of strain gauge electronic, starting the race track punch and removal the drawing part from thedie;

7. Reading of the drawing force registered at oscillograph;

8. Measuring the effective height of the piece.

Tab. 2.Experimental conditions and results obtained from the deformationstrips of sheet $A 5$ and $A 3 k$

\begin{tabular}{|c|c|c|c|c|c|c|c|c|}
\hline Nr. exp. & $\mathrm{d}_{\mathrm{p}}[\mathrm{mm}]$ & $\mathrm{d}_{\mathrm{m}}[\mathrm{mm}]$ & $\mathrm{j} / 2[\mathrm{~mm}]$ & $\mathrm{A}_{\mathrm{q}}\left[\mathrm{mm}^{2}\right]$ & $\mathrm{Q}[\mathrm{daN}]$ & $\varepsilon[\mu \mathrm{m} / \mathrm{m}]$ & $\mathrm{U}[\mathrm{V}]$ & $\mathrm{F}[\mathrm{daN}]$ \\
\hline 1 & 5,52 & 6 & 0,24 & 0 & 0 & 0 & 1,9 & 173,8 \\
\hline 5 & 7,86 & 8,5 & 0,32 & 83,8 & 25,15 & 34,6 & 3,4 & 245,84 \\
\hline
\end{tabular}

Calibration was performed in accordance with paragraph 3.5. and drawing force values were calculated using the equation of the calibration curve (5) be valid for $\mathrm{F}<1000$ daN.
- Recording diagrams force - race

The diagrams force - race $(F-h)$ experimentally obtained are presented in Tab. 3, together with the corresponding parts[4].

Tab. 3. Parts and diagrams force - race obtained experimentally

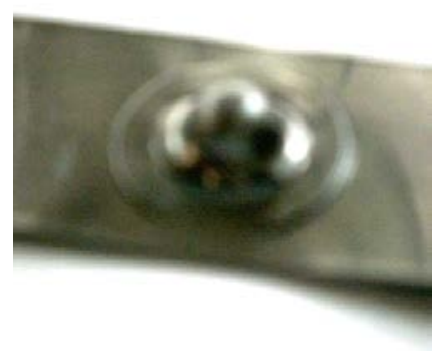

a) Piece from $\mathrm{A5}$

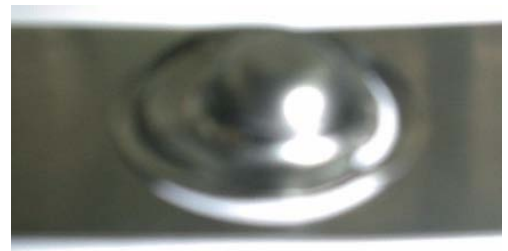

c) Piece from A3K

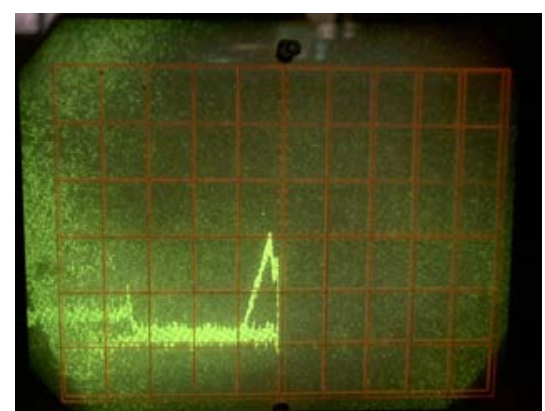

b) The diagram F-h for A5



d) The diagram F-h for A3K 
"Mircea cel Batran" Naval Academy Scientific Bulletin, Volume XIX - 2016 - Issue 2

The journal is indexed in: PROQUEST / DOAJ / Crossref / EBSCOhost / INDEX COPERNICUS / DRJI / OAJI /

JOURNAL INDEX / I2OR / SCIENCE LIBRARY INDEX / Google Scholar / Academic Keys/ ROAD Open Access I

Academic Resources / Scientific Indexing Services / SCIPIO I JIFACTOR

\section{CONCLUSIONS}

Analyzing the experimental variations drawing force can draw the following conclusions:

0 In the same clearance a drawing of the thinning can observe an increase of drawing force with increasing dimensions of active elements because it increases the volume of the material deformed;

o For the same diameter of the die, there was a slight decrease of drawing force with increasing the clearance because deformation conditions are improving.

Force values determined by calculation using literature relations are closer, generally smaller than those experimental, higher differences appeared than those obtained by simulation.The differences are due to the following factors: deformations technological system consists of press, the die and part, wear press, position errors of the die to press, as well as of the strip in stamping die and die, approximating in simulation of the friction coefficient existing practice (influence coefficient of friction is importance). It is worth mentioning that in experiments was used a mineral oil which was added to graphite, which was applied to the plate active surface or of the blank comes into contact with it.

\section{BIBLIOGRAPHY}

[1] Romanovski, V.P., Ştanţarea şi matriţarea la rece, (traducere din limba rusă), Editura Tehnică, 1970

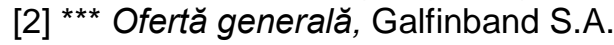

[3] Drăgănescu, F., ş.a., Matriţa dinamometrică cu elemente active schimbabile rapid pentru cercetarea ambutisării pieselor cilindrice mici, Conferinţa naţională de tehnologii şi utilaje pentru prelucrarea prin deformare plastică la rece, vol.2, Bucureşti, 28-29 may 1993

[4] Chioibas, A., Cercetări privind influenta condițiilor de deformare asupra calității pieselor ambutisate, Teza de doctorat, UPB, 2004

[5] Hoffmmann, K., An introduction to measurements usingstrain gages, Hottinger Baldwin Messtechnik GembH, Darmstadt, 1989

[6] *** The measurement and automation-catalog 2000, National Instruments, S.U.A. 2000

[7] Ciocârdia, C., Drăgănescu, F., Tehnologia presării la rece , Îndrumar de laborator, U.P.B.

[8] *** Inductive Displacement Transducers, Hottinger Baldwin Messtechnik GMBH

[9] Ciocîrdia, C., Drăgănescu, FI., ş.a., Tehnologia presării la rece. Editura Didactică şi Pedagogică, Bucureşti, 1991 